\title{
Flow Cytometric Detection of Natural Killer Cells and Natural Killer T Cells Changes in the Blood of Patients with Chronic Hepatitis C Virus Infection in an Egyptian University Hospital
}

\author{
Marwa Mostafa Shalaby ${ }^{1}$, Kareman Ahmed Eshra ${ }^{1}$, Radwa Mahmoud Sharaby ${ }^{2}$ \\ and Ibrahim Fathy Amer ${ }^{3}$
}

${ }^{1}$ Department of Microbiology and Immunology, Faculty of Medicine, Tanta University, Egypt

${ }^{2}$ Department of Clinical Pathology, Faculty of Medicine, Tanta University, Egypt

${ }^{3}$ Department of Hepatology, Gastroentrology and Infectious Diseases, Faculty of Medicine, Kafr

El-Sheikh University, Egypt

*Corresponding author

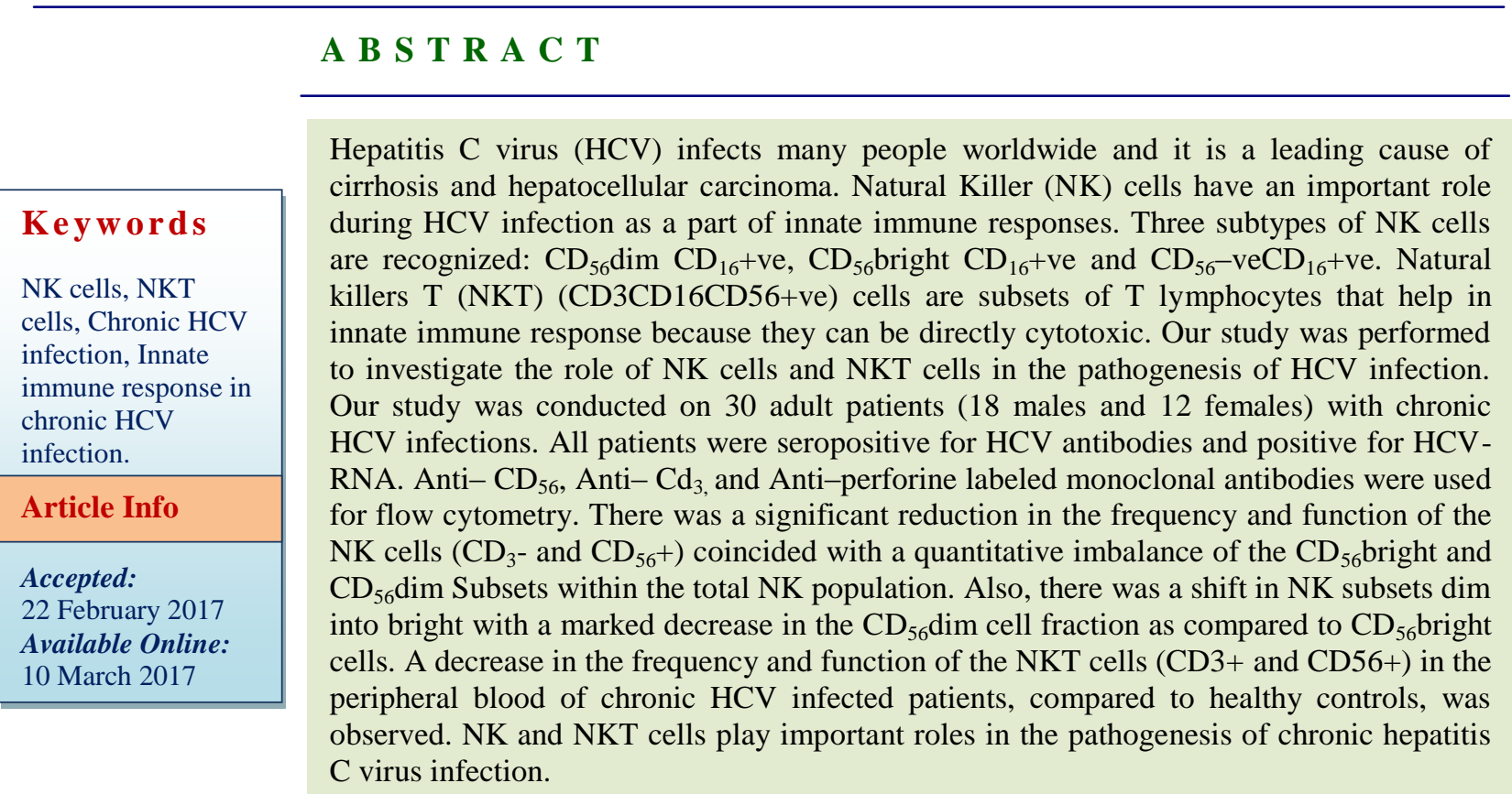

\section{Introduction}

Hepatitis $\mathrm{C}$ virus (HCV) infections are a major health problem worldwide, infecting over $3 \%$ of the populations. According to the world health organization (WHO) estimates, 170 million peoples have chronic $\mathrm{HCV}$ infections and that 3 to 4 million new infections occur every year (Burke and Cox,
2010). Egypt has the highest HCV prevalence in the world, where about 10-20\% of population is infected with HCV. Subtype $4 \mathrm{a}$ represents about $90 \%$ of Egyptian HCV infections (Mohamoud et al., 2013). Hepatitis $\mathrm{C}$ viral persistence occurs in about $70-80 \%$ of patients, and is associated with chronic liver 
inflammation and an increased risk for cirrhosis and hepatocellular carcinoma.

The immune responses of the patients play a major role in the pathogenesis of infection; however the role of the adaptive and innate host immune responses and their respective effect or functions have not been well studied (Rehermann and Nascimbeni, 2005).

Most of the immunologic studies of $\mathrm{HCV}$ were focused on the adaptive immune response. In acute self-limited HCV infection, severe response of the specific $\mathrm{CD}_{4}$ and $\mathrm{CD}_{8}$ $\mathrm{T}$ cell was observed and $\mathrm{HCV}$ antigens were recognized by more than $10 \%$ of all peripheral blood lymphocytes (Urbani et al., 2005). HCV-specific $\mathrm{CD}_{4}$ and $\mathrm{CD}_{8} \mathrm{~T}$ cells recruit to the liver at the same time with the onset of liver injury. In chronic $\mathrm{HCV}$ infection, ineffective and functionally impaired HCV-specific $\mathrm{T}$ cells occurred (Lechner et al., 2000).

On the other hand, the role of innate immune response was not thoroughly studied in spite of that the innate immune responses play an important role in early effector functions and in the activation and maintenance of adaptive immune responses. Innate immune response is responsible for persistent viral infections. So, defects in innate immune responses may affect the control of viral replication either directly or indirectly. Innate immune responses should be studied well because also the liver is selectively enriched in components of the innate immune system (Salem et al., 2010)

The innate immune system is consisting of epithelial surfaces, plasma proteins and many cells such as NK cells, macrophages and dendritic cells. These components play very important role in the immune responses against HCV (Torres et al., 2011). NK cells are large bone marrow - derived cytotoxic granular lymphocytes that differ from $\mathrm{T}$ lymphocytes in that they do not express T-cell antigen receptors or the pan $-\mathrm{T}$ marker $\mathrm{CD}_{3}$, but are $\mathrm{CD}_{3}-\mathrm{CD}_{56}+$. They comprise $5-20 \%$ of lymphocytes in the spleen, liver, and peripheral blood, and are capable of spontaneously killing tumor and virusinfected cells (Biron, 2010).

The antigens which can be used as NK cell markers for clinical and basic research purposes are $\mathrm{CD}_{56}$ and sometimes $\mathrm{CD}_{16} \cdot \mathrm{CD}_{56}$ antigen is expressed by all human peripheral blood cells capable of non MHC restricted cytotoxicity; it appears to be identical to the neural cell adhesion molecule (NCAM). The $\mathrm{CD}_{56}$ antigen itself appear not to participate directly in NK killing of most target cells, although a recent report suggests that $\mathrm{CD}_{56}$ can mediate adhesion of NK cells to $\mathrm{CD} 56$ +ve tumour cell lines Vivier et al., (2009). NK cells were defined phenotypically as CD ${ }_{56}+\mathrm{ve}, \mathrm{CD}_{3}$-ve lymphocytes (Janeway and medzhitov, 2003)

Three subtypes of NK cells are recognized: $\mathrm{CD}_{56}$ dim $\mathrm{CD}_{16}+\mathrm{ve}, \mathrm{CD}_{56}$ bright $\mathrm{CD}_{16}+\mathrm{ve}$, and CD ${ }_{56}-$ veCD $16+v e$. $\mathrm{CD}_{56}$ dim $\mathrm{CD}_{16}+\mathrm{ve}$ and $\mathrm{CD}_{56}$ bright $\mathrm{CD}_{16}+\mathrm{ve}$ subsets are the more cytotoxic subsets of NK cells lizuka et al., (2008). $\mathrm{CD}_{56} \operatorname{dim} \mathrm{CD}_{16}+\mathrm{ve}$ subset represent 90 $\%$ of the peripheral blood mononuclear cells (PBMN) NK cells and is the most cytotoxic type cooper et al., (2005), while, $\mathrm{CD}_{56}$ bright $\mathrm{CD}_{16}+$ ve represent $10 \%$ of PBMN- NK cells (Bjorkstrom et al., 2010).

Natural killer T (NKT) were defined as cells express a TCR along with NK cell receptors such as $\mathrm{CD}_{16}, \mathrm{CD}_{56}, \mathrm{CD}_{69}, \mathrm{CD}_{94}$. Like $\mathrm{T}$ cells, human NKT cells can be $\mathrm{CD}_{4}$ positive (Flesch et al., 2000). NKT cells are $\mathrm{CD}_{3}+\mathrm{CD}_{56}+$ (Olszak et al., 2012). These cells can be directly cytotoxic, produce an array of cytokinesas (IFN)- $\gamma$, IL4, Granulocyte macrophage colony stimulating factor and 
chemokines (Godfrey et al., 2004), Disruption of NKT cell numbers or function results in severe deficits in immune surveillance against virus infected cells and tumor cells (Bienemann et al., 2011). Decreased frequency of $\mathrm{CD}_{3}+\mathrm{CD}_{56}+$ in chronic $\mathrm{HCV}$ compared to healthy control liver has been reported (Nandan et al., 2012).

NK cells differ from $T$ cells in they do not need antigen-specific priming to recognize virus-infected cells, they produce cytotoxicity Once activated. Their Antiviral effects occur through released cytokines, such as interferon (IFN) $-\gamma$ and tumor necrosis factor (TNF)- $\alpha$, interleukin-12 and many chemokines and/or cytolysis of abnormal or infected cells through secretion of granzyme or perforin (Dunn et al.,., 2007). Also they have antiviral effect against many human viruses, such as the herpes viruses, Epstein-Barr virus, and Cytomegalovirus (Kuijpers et al., 2008). NK cells recognize target cells via $\mathrm{CD}_{16}$ receptor binding of $\mathrm{IgG}$ complexes on opsonized targets or specific NK receptor binding of target ligands (Lanier, 2005).

However, $\mathrm{HCV}$ can modulate the innate immune response as following, interferon- $\gamma$ released by NK cells decreased by binding of $\mathrm{HCV}$ E2 protein to the $\mathrm{NK} \mathrm{CD}_{81}$ receptor. Also, HCV core protein decreasing NK cell activity against infected cells by increasing major histocompatibility complex class I expression on infected hepatocytes,. HCV depresses dendritic cell function and number these dendritic cells release cytokines IL-12 and IL-15, which augment NK cell function and survival. However, HCV increases the regulatory $\mathrm{T}$ cell population in the liver. Regulatory $\mathrm{T}$ cells secrete transforming growth factor- $\beta$ and IL-10 to decrease NK cell function. $\mathrm{HCV}$ proteins ablate signaling pathways in the infected cell to block intracellular pathways associated with innate immunity. In the infected cell, the nonstructural proteins of $\mathrm{HCV}$ interact with various host adaptor molecules to block type I interferon induction pathways and the antiviral effects of interferon (Amadei et al., 2010; Dessouki et al., 2010 and Feld et al., 2010). Chronic HCV infection is associated with reduced NK cell frequency and function (perforin and interferon- $\gamma$ secretion) in both the peripheral blood and in the liver (Meier et al., 2005). However, the definitive role of NK cells in pathogenesis of chronic HCV infection is still under investigation (Lee et al., 2010).

The use of flowcytometry (FCM) to analyze cell populations represents a major technologic advance in medicine. It has proven to be a valuable research tool in the study of leukemia, lymphoma, autoimmunity, tumor cell kinetics and chromosomal markers (Ananya and Sally, 2014). In recent years, this technique has become partical for use in clinical laboratories (Ornatsky et al., 2010).

Five factors were leading to development of FCM: Laser technology, monoclonal antibodies, fluorochrome chemistry, cytochemical staining and computer processing. FCM is defined as a process in which individual cells or other biological particles are made to pass in a single file, in a fluid stream "isotonic sheath fluid", through a beam of light and by sensors, physical and chemical characteristics of cells or particles can be known (Lo and Gattardo, 2008). The light source is typically a laser. As the cells pass through the laser beam, photons of light are emitted and scattered; these photons are separated then collected by forward and side light scatter detectors. The detected light signal is converted into a digital with the aid of photomultiplier tubes. The digital signal generated by each cell is proportional to its light emission and is plotted on a histogram (Oranatsky et al., 2010). 


\section{Materials and Methods}

The present study was carried out on 30 chronic $\mathrm{C}$ virus infected patients and 10 healthy persons. The patients selected from the hepatology, gastroentrology and infectious diseases department of Tanta University Hospitals from January 2015 to December 2015.All selected cases are of low viremia (viral load was range from $10.000-100.000$ $\mathrm{IU} / \mathrm{mL}$ by quantitative RT-PCR for HCV RNA (Tanqman 48 - Roche).

\section{Exclusion criteria}

Exclusion criteria were patients with high and very high viremia, patients with other viral infections, patients with malignancy, patients under steroid treatment and chemotherapy, and patients under interferon treatment.

\section{All individuals were subjected to the following}

Through history taking, Complete clinical examination, Abdominal sonography (In patients only), and laboratory investigations which include: Complete blood count (CBC), Erythrocyte sedimentation rate, Liver function tests: Serum total and direct serum bilirubin, Serum Alanine Aminotransferase (ALT), Serum Aspartate Aminotransferase (AsT), Serum albumin, Prothrombin time (PT), antihepatitis C Virus antibodies (anti - HCV) by ELISA, R-T polymerase chain reaction (PCR) for quantitative HCV-RNA, and Flowcytometric assessment of: Frequency and phenotype NK cells using CD3/CD56 antibodies, NK cell function using antiperforin antibodies.

\section{Sampling}

A venous blood sample $(10 \mathrm{ml})$ was withdrawn from each individual under aseptic condition by a clean venipuncture and then dispensed into four tubes:
1. $2 \mathrm{ml}$ of blood was delivered into EDTA containing tube $(6 \mathrm{mg} \%)$ for $\mathrm{CBC}$ and flowcytometry.

2. $1.8 \mathrm{ml}$ of was delivered into a tube containing ( $0.2 \mathrm{ml}$ trisodium cirate), in which plasma was separated by centrifugation at $4000 \mathrm{rpm}$ for 10 minutes, top yellow plasma layer was withdrawn for PT.

3. $1.6 \mathrm{ml}$ of blood was delivered into tube containing ( $0.4 \mathrm{ml}$ trisodium citrate) for ESR.

4. The rest of blood was delivered into plan tube for liver function tests, ELISA and PCR.

\section{Flowcytometry process}

\section{Equipments}

Flowcytometer BDFACS Calbur BD bioscience (USA), Automatic pipettes, centrifuge, vortex, and standard flowcytometer tubes (falcon tubes, $5 \mathrm{ml}$ polyestern round bottom tube $12 \times 75 \mathrm{~mm}$, non pyrogenic and sterile from BD bioscience system). Each tube was labeled with the patient's name.

\section{Reagents}

1. Monoclonal antibody labeled.

- Anti-CD 56 PE

- Anti - Cd 3 PERCP

- Anti - perforine FITC

(BD Pharmingen ${ }^{\text {TM1 }}$ Catologue number: S57145, Lot: S 1322).

2. Lysing solution: to lyse the RBCs provided by BD.

3. Washing solution which is composed of a Phosphate buffered saline (PBS)

4. Isotype control:

- PE Mouse IgG2a.

-PERCP Mouse IgG2a.

-FITC Mouse IgG2a. 


\section{Method}

1. $100 \mathrm{ul}$ of the blood was mixed with $10 \mathrm{ul}$ of the anti- CD 56 PE Labeled and CD 3 monoclonal antibody PC-Labeled, mixed well by vortex and incubated in the dark at 4oc for 30 minutes.

2. $1 \mathrm{ml}$ of the lysing fluid $(1 \mathrm{x})$ was added.

3. After mixing well by vortex and incubated in the dark at $4^{\circ} \mathrm{c}$ for 20 minutes, centrifuged then the supernatant was discarded.

4. We washed once using $3 \mathrm{ml}$ of (PBS) mix and vortexed at $3000 \mathrm{rpm}$ for 5 minutes.

5. The supernatant was discarded after wash.

6. $1 \mathrm{ml}$ of permeabilizing solution was added for 10 minutes at room temperature.

7. We washed once using $3 \mathrm{ml}$ of (PBS) mix and vortexed at $3000 \mathrm{rpm}$ for 5 minutes and discarded the supernatant.

8. $10 \mathrm{u}$ anti - perforine antibodies FITC labeled was added and incubated in the dark at $4^{\circ} \mathrm{c}$ for 30 minutes.

9. Then we washed twice using $3 \mathrm{ml}$ of (PBS) for each one, mixed and vortexed at $3000 \mathrm{rpm}$ for 5 minutes and discarded the supernatant.

10. $0.5 \mathrm{ml}$ of PBS was added containing paraformaldehyde $(0.5 \%)$ to stabilize the interaction to be read immediately or after a while.

\section{Flowcytometric analysis}

1. The full alignment procedure was performed for adjusting forward scatter. Side scatter and photomultiplier tube (PMT).

2. The sample tube was introduced in the machine and forced in the sheath by the sample pressure "run button" where the laser scatter was received on the both forward scatter detectors and scale to show the cell population in a basic histogram and to adjust the regions.

3. 10.000 events (cells) at least were passed in front of the laser (488nm) for each case from which the lymphocytes were selectively gated (surrounded by a line to separate them from neutrophils and monocytes in the basic dot blot) for immunophenotyping. The fraction of cells coated by monoclonal was determined inside the gated population of lymphocytes and assessed in a single dot blot. So, the data was plotted on many dot blots. The first one was forward scatter (FS) versus side scatter (SS) where the lymphocyte cells are electronically-gated. The other blots were $\log$ fluorescence skewing the frequency of the cells that are positive or negative for the used antibodies (Figs. 1-7).

\section{Results and Discussion}

There was significant lower percentage of peripheral NK and NKT cells among patients when compared to controls. The mean level in patients was 9.37for NK cells and 6.24 for NKT cells (Table 1). A high percentage of CD56 ${ }^{\text {bright }}$ NK cells subsets in patients compared to controls were found, while percentage of CD56dimNK cells subsets was higher in controls than in patients. These differences were statistically significant (Table 2). We also noticed that perforin production by peripheral NK cells was significantly lower in patients than in controls as the mean level in patients was 48.67 and in controls was 71.84 (Table 3). Similarly, the study showed that perforin production by peripheral NKT cells was significantly lower in patients than in controls as the mean level in patients was 31.57 and in controls was 51.94 (Table 4). The present study investigated the frequency of peripheral NK cells and NKT cells in 30 patients with 
chronic HCV infection, focusing on their subsets and function (perforin production) as compared to10 healthy controls.

Upon analysis of the frequency and function, we found that there were decrease in the frequency of these cells [The mean level in patients was 9.37 for NK cells and 6.24 for NKT cells (Table 1)], together with a quantitative imbalance of the $\mathrm{CD}_{56}$ bright and
$\mathrm{CD}_{56 \mathrm{dim}}$ subsets within the total NK population. There was a shift in NK subsets from dim into bright, with a marked decrease in the $\mathrm{CD}_{56 \mathrm{Dim}}$ cell fraction $(26.7 \%)$ as compared to $\mathrm{CD}_{56}$ bright cells $(73.3 \%)$. As regard to the function of cells (perforin production) by both NK and NKT cells, it was significantly decreased ( $\mathrm{P}$ value was 0.012 and 0.001 , respectively).

Table.1 Comparison between chronic HCV patients and controls as regard the frequency of peripheral NK and NKT cells

\begin{tabular}{|c|c|c|c|c|c|c|c|c|}
\hline & & Rang & & Mean & & S. D & t. test & p. value \\
\hline \multirow{2}{*}{ NKT cells } & Patients & 0.46 & $\begin{array}{ll}-\quad 15.98 \\
\end{array}$ & 6.24 & \pm & 4.86 & \multirow{2}{*}{3.264} & \multirow{2}{*}{$0.002 *$} \\
\hline & Control & 4.75 & -21.32 & 11.84 & \pm & 4.13 & & \\
\hline \multirow{2}{*}{ NK } & Patients & 2.43 & $-\quad 22.74$ & 9.37 & \pm & 4.59 & \multirow{2}{*}{3.163} & \multirow{2}{*}{$0.003^{*}$} \\
\hline & Control & 4.94 & -23.54 & 14.83 & \pm & 5.17 & & \\
\hline
\end{tabular}

Table.2 comparison between chronic HCV patients and controls as regard the frequency of subsets of peripheral NK

\begin{tabular}{|c|c|c|c|c|c|c|}
\hline \multirow{3}{*}{ Subsets of NK cells } & \multicolumn{4}{|c|}{ Groups } & \multirow{2}{*}{\multicolumn{2}{|c|}{ Chi-square }} \\
\hline & \multicolumn{2}{|c|}{ Patients } & \multicolumn{2}{|c|}{ Control } & & \\
\hline & $\mathbf{N}$ & $\%$ & $\mathbf{N}$ & $\%$ & $\mathbf{X}^{2}$ & P-value \\
\hline CD56 $6^{\mathrm{dim}}$ & 8 & 26.7 & 8 & 80 & \multirow{3}{*}{8.892} & \multirow{3}{*}{$0.003 *$} \\
\hline CD56 ${ }^{\text {bright }}$ & 22 & 73.3 & 2 & 20 & & \\
\hline Total & 30 & 100 & 10 & 100 & & \\
\hline
\end{tabular}

Table.3 Comparison between chronic HCV patients and controls as regard the perforin production by peripheral NK cells

\begin{tabular}{|l|l|l|ll|l|l|l||}
\hline \begin{tabular}{|l} 
NK cells \\
production
\end{tabular} & Perforin & Range & Mean & \pm S. D & t. test & p. value \\
\hline \hline \multirow{2}{*}{+ ve } & Patients & 10 & -86 & 48.67 & \pm 26.84 & \multirow{2}{*}{2.642} & \multirow{2}{*}{$0.012^{*}$} \\
\cline { 2 - 9 } & Control & 54 & -85 & 71.84 & \pm 11.26 & & \\
\hline \multirow{2}{*}{-ve } & Patients & 12 & -90 & 45.95 & \pm 20.57 & \multirow{2}{*}{2.744} & $0.009 *$ \\
\cline { 2 - 8 } & Control & 14 & -42 & 27.42 & \pm 9.37 & & \\
\hline
\end{tabular}


Table.4 comparison between chronic HCV patients and controls as regard the perforin production by peripheral NKT cells

\begin{tabular}{|l|l|l|lll|l|l||}
\hline $\begin{array}{l}\text { NKTcellsPerforin } \\
\text { production }\end{array}$ & \multicolumn{2}{|l|}{ Range } & Mean & \pm S. D & t. test & \multirow{2}{*}{ p. value } \\
\hline \multirow{2}{*}{$+\mathbf{v e}$} & Patients & 16 & -52 & 31.57 & \pm 11.25 & \multirow{2}{*}{5.162} & \multirow{2}{*}{$0.001^{*}$} \\
\cline { 2 - 9 } & Control & 34 & -70 & 51.94 & \pm 9.25 & & \multirow{2}{*}{$0.001^{*}$} \\
\hline \multirow{2}{*}{$-\mathrm{ve}$} & Patients & 24 & -94 & 58.73 & \pm 21.68 & \multirow{2}{*}{3.674} & \\
\cline { 2 - 8 } & Control & 12 & -50 & 31.83 & \pm 13.52 & & \\
\hline
\end{tabular}

Fig.1 Dot blot showing forward scatter (FS) versus side scatter (SS) where the lymphocyte cells are electronically-gated patient

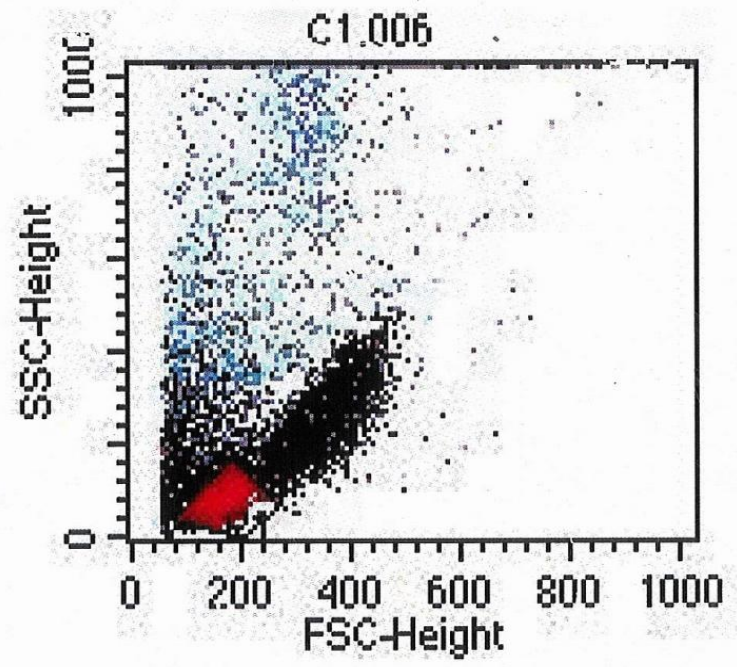

Fig.2 Dot blot gated on lymphocytes showing CD3-/CD56+ (UL:5.6\%) in which CD3-/CD56+ $\operatorname{dim}(\mathrm{R} 3: 2.0 \%)$ and CD3-/ CD56+ bright (R2:3.6\%) and CD3+/CD56+ (UR:1.02\%)

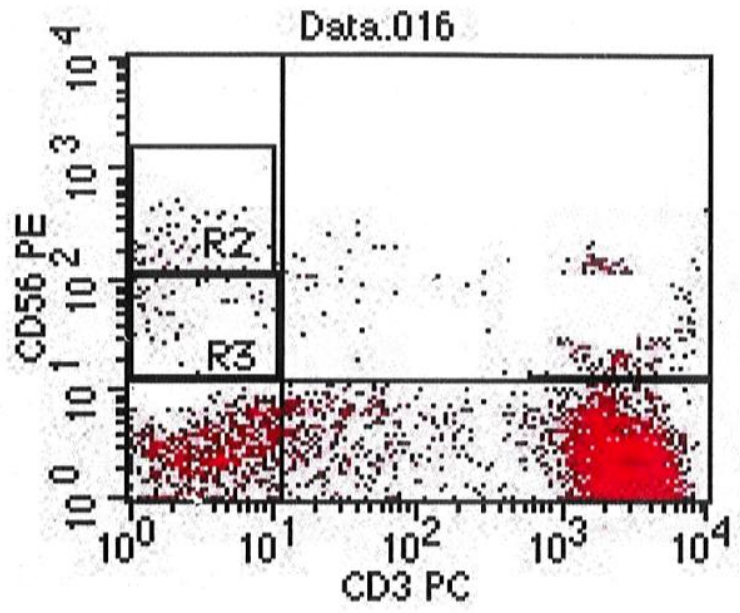


Fig.3 Dot blot gated on CD3-/CD56+ showing perforin production by peripheral NK cells (43\%) with perforin production by CD3-/CD56+ dim (R4: 32\%) and CD3-/CD56+ bright (R5:11 \%)

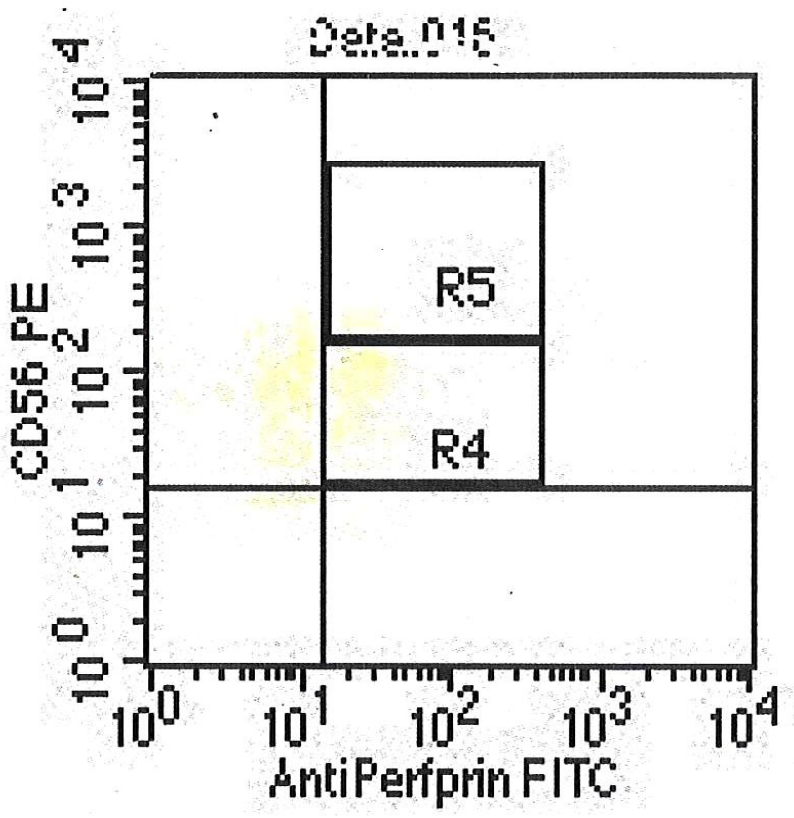

Fig.4 Dot blot gated on CD3+/ CD56+ showing perforin production by peripheral NKT (UR: $0.25 \%)$

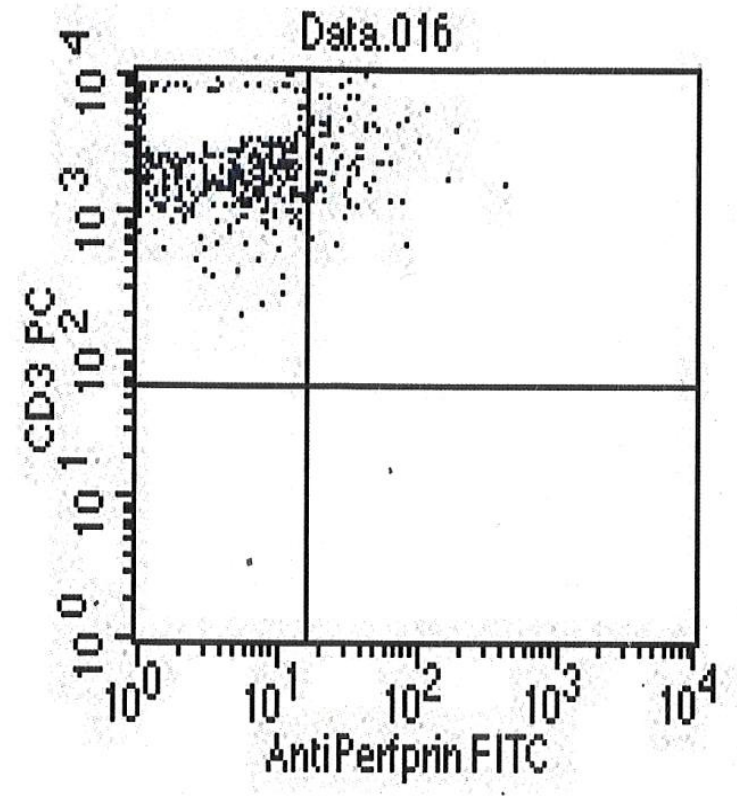


Fig.5 Dot blot gated on lymphocytes showing CD3-/ CD56+ (UL: 8.2\%) in which CD3-/ CD56+ dim (R3: 6.2\%) and CD3-/ CD56+ bright (R2: 2\%) and CD3+/CD56+ (UR: 1.8\%)

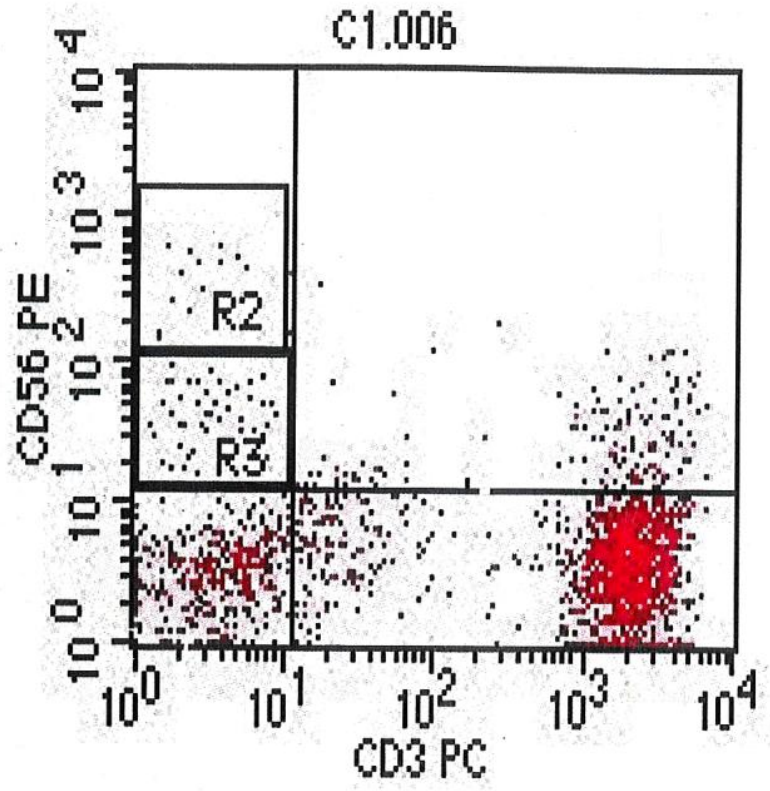

Fig.6 Dot blot gated on CD3-/ CD56+ showing perforin production by peripheral NK cells (74.3\%) in which perforin production by CD3-/ CD56+dim (R4: 60.3\%) and by CD3-/ CD56+ bright (R5: 14\%)

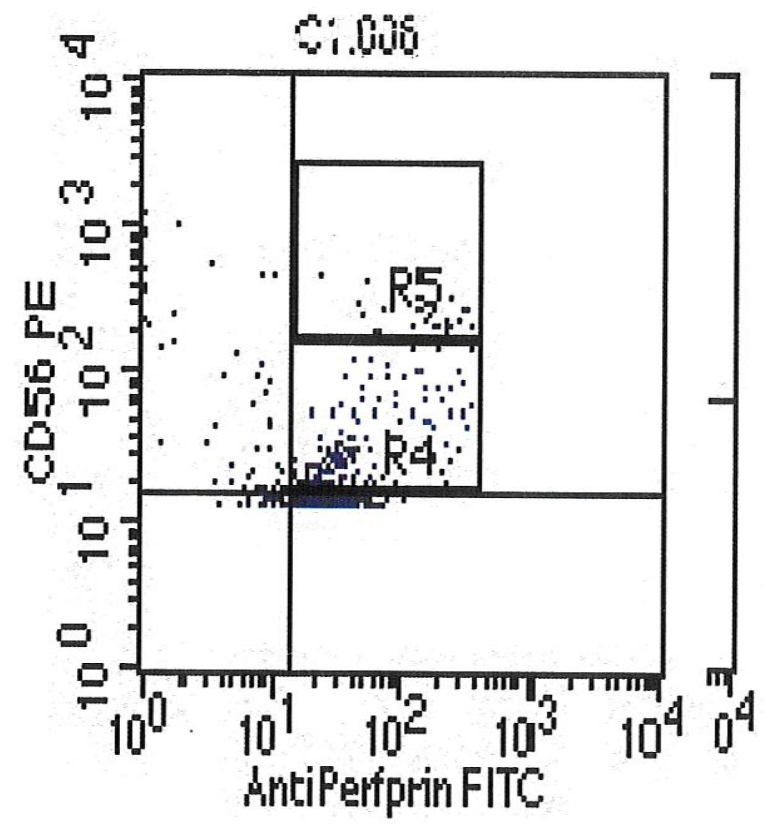


Fig.7 Dot blot gated on CD3+/ CD56+ showing perforin production by peripheral NKT (UR: 0.47\%)

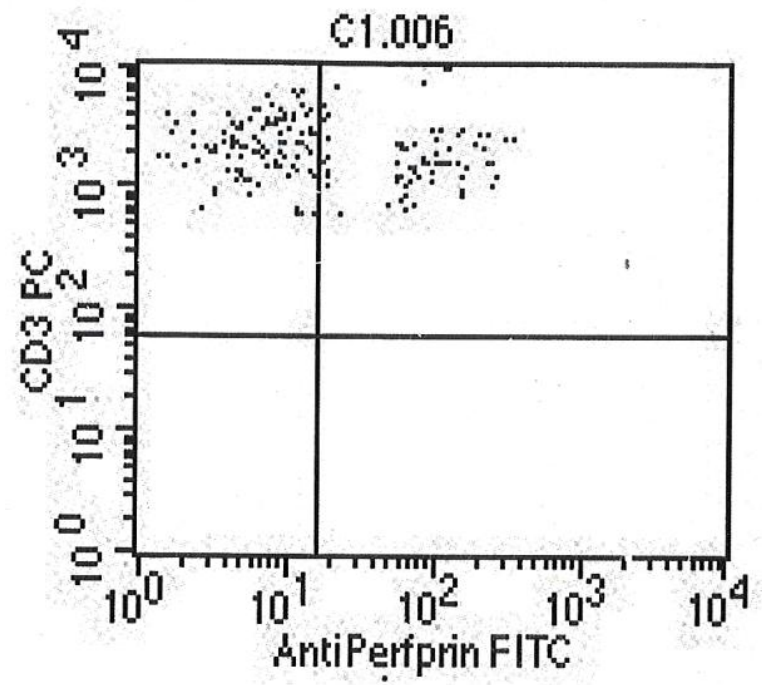

Meier et al., (2005) and Rivero et al., (2013) detected similar results to that of our study, They revealed that this shift influenced phenotype and functional capacity (gamma interferon production capacity of the NK subset $\mathrm{CD}_{56 \mathrm{dim}}$ observed in $\mathrm{HIV}$ and $\mathrm{HCV}$ patient were found to be associated with a significant reduction in serum levels of the innate cytokine interleukin 15 (IL-15). $\mathrm{CD}_{56}$ dim and $C_{56 b r i g h t}$ subsets differ in their perforin content, where $\mathrm{CD}_{56 \text { bright }}$ cells are low in perforin, $\mathrm{CD}_{56 \mathrm{dim}}$ cells express higher levels of perforin. Upon analysis of perforin expression by NK subsets from control, they found that in $\mathrm{HIV}+$ and $\mathrm{HCV}+$ individuals, there was an altered subset distribution, where the percentage of $\mathrm{CD}_{56 \mathrm{dim}}$ perforin high $\mathrm{NK}$ cells was diminished resulting in a lower level of perforin expression in the total NK pool.

Also, Neumann et al., (2001) found the same results to us among patients with $\mathrm{HCV}$ infection, but not among patients who cleared $\mathrm{HCV}$ infection after antiviral therapy or among healthy individuals. Additionally, Elletier et al., (2010) demonstrated that NK cells are activated during acute HCV regardless of infection outcome and may play an indirect role through induction and priming of $\mathrm{T}$ cell responses and in clearance of $\mathrm{HCV}$ infection.

In line with this, a Japanese study demonstrated that combination therapy of pegylated interferon (IFN- $\alpha$ ) and ribavirin improved NK distribution and functions, and significantly increased their numbers among HCV - cleared patients. The authors observed that relapsing patients failed to recover $\mathrm{NK}$ functions and numbers, these results suggest that $\mathrm{NK}$ alteration caused by $\mathrm{HCV}$ infection may be due to the impairment of cellular immune response, which might result in chronic diseases. Also, it has been shown that NK cells isolated from patients with chronic $\mathrm{HCV}$ were less effective in killing hepatoma cells and in producing IFN- $\gamma$ than NK Cells from healthy donors Dessouki et al., (2010).

Another study performed by Golden- Mason et al., (2008) showed that the frequency and cytotoxic capacity of the overall NK peripheral pool was decreased in patients with HCV infection. Similarly, Tom et al., (2012) detected that NKT cells were significantly decreased among chronic HCV - infected patients, they suggested that possible explanations for the decreased frequency of 
NK and NKT cells in chronic HCV patients may include apoptosis of the cells, down regulation of the cell receptors, decreased production, or compartmentalization into peripheral organs, In addition, binding of $\mathrm{HCV}$ E2 protein to $\mathrm{CD}_{81}$, a human cell surface molecule found on the surface of almost all nucleated cells, blocks NK cell function, and provides the virus with an efficient immune escape strategy capable of limiting the antiviral activity of NK cells early in the infectious process Golden- Mason and Rosen (2013).

In order to explain if the decreased frequency of peripheral NK and NKT cells in chronic HCV patients is due to accumulation in the liver or not, many studies have shown, using liver biopsy, that the frequency of NK and NKT cells in the liver decreased in parallel with the histological progression of $\mathrm{HCV}$, and that their cytotoxicity and ability to secrete cytokines correlated inversely with the degree of liver affection. It has been demonstrated that cytolytic activity of NK and NKT cells is inversely associated with the stage of liver fibrosis, suggesting that these cells may be protective against liver disease progression Gao and Radaeva, (2013).

In our study we didn't compare cells between peripheral blood and liver. Contrarily, Cormac et al., (2014) showed an enrichment of NK cells in healthy liver as compared to the peripheral blood where they observed more NK cells in the liver of uninfected individuals as compared to the blood $(52.27 \%$ vs. $9.8 \%, \mathrm{p}<0.01)$. This difference was not seen in the setting of $\mathrm{HCV}$ infection, though this has been suggested to be a consequence of relative dilution due to $\mathrm{T}$-cell infiltration which is supported by the increased T: NK cell ratio in HCV- infected livers. Given the altered distribution of the functionally distinct $\mathrm{CD}_{56}$ bright and $\mathrm{CD}_{56 \text { dim }} \mathrm{NK}$ cell subsets in secondary lymphoid tissues and the liver, they investigated whether these populations were skewed in the context of HCV infection. As described for other tissue-resident NK cells, they observed an enrichment of the immunoregulatory $\mathrm{CD}_{56}$ bright population over the cytotoxic $\mathrm{CD}_{56}$ dim population in the liver versus the blood of both $\mathrm{HCV}$ - infected $(\mathrm{p}=0.0005)$ and - uninfected $(\mathrm{p}<0.0001)$ individuals. This enrichment was striking, with $\mathrm{CD}_{56}$ bright $\mathrm{NK}$ cells as they accounting for up to $85 \%$ of the total NK cell population in the liver of some individuals. As such, no difference in the subset distribution was observed among infected or uninfected subjects, demonstrating that certain NK cell populations universally compartmentalize to the liver, which remain relatively unperturbed in $\mathrm{HCV}$ infection. Pembroke et al., (2014) also found a similar result to Cormac et al., (2014).

In general, our study indicated the regulated effects $\mathrm{HCV}$ on the number and function of NK and NKT cells. This regulated effect can be suggested to be among the factors that mediate the escape mechanisms of HCV from anti-viral host response.

\section{References}

Amadei, B., Urbani, S., Cazaly, A., et al. 2010. Activation of natural killer cells during acute infection with hepatitis $\mathrm{C}$ virus Gastroenterol., vol138 (pg. 1536-45).

Ananya, M. and Sally, R. 2014. What is flow cytometry? Last Updated: Oct 8, 2014.

Bienemann, K., Iouannidou, K., Schoenberg, K., et al. 2011. NK T cells frequency in peripheral blood of Caucasian children anadolescent: the absolute I NKT cell count is stable from birth to adulthood. Scand J. Immunol., Jun 14.

Bojorkstrom, N.K., Ljunggren, H.G., and Sandberg, J.K. 2013. Natural killer cell subtypes and markers in human PBMC posted on Andrea in PBMC basics with 0 comments CD 56 negative $\mathrm{NK}$ cells: origin, function, and role in chronic viral disease. Trends Immunol., 31(11): 401-6.

Brion, C.A. 2010. Expansion, maintenance, and memory in NK and $\mathrm{T}$ cells during viral infections: Responding to pressures for defense and regulation. PloS Patholg., 6(3): e1000816.Review. 
Burke, K.P. and Cox, A.L. 2010. Hepatitis C virus evasion of adaptiveimmune responses: a model for viral persistence. Immunol. Res., 47(1-3): 216-27.

Cooper, M.A., Fehniger, T.A., and Caligiuri, M.A. 2005. The biology of human natural killer cell subsets. Trend Immunol., 22: 633-640.

Cormac, C., Christoph, T.B., Daniela, K., Patrick, C., Jasneet, A., Michelle, T., and Georg, M. 2014. Chronic HCV infection affects the NK cell phenotype in blood more than in the liver. PLoS ONE, 9(8) e105950.doi:10.1371.

Dessouki, O., Kamiya, Y., Nagahama, H., et al. 2010. Chronic hepatitis C viral infection reduces NK cell frequency and suppresses cytokine secretion: reversion by anti-viral treatment. Biochem. Biophys. Res. Commun., 393: 331-7.

Dunn, C., Brunetto, M., Reynolds, G., Christophides, T., Kennedy, P.T., Lampertico, P., Das, A., Lopes, A.R., Borrow, P., Williams, K., Humphreys, E., Afford, S., Adams, D.H., Bertoletti, A., and Maini, M.K. 2007. Cytokines induced during chronic hepatitis B virus infection promote a pathway for NK cell-mediated liver damage. J. Exp. Med., 204: 667-80.

Elletier, S., Drouin, C., Bedard, N., Khakoo, S.I., Bruneau, J. et al. 2010. Increased degranulation of natural killer cells during acute HCV correlates with the magnitude of virus specific $\mathrm{T}$ cell responses. $J$. Hepatol., 53: 805-816.

Feld, J.J., Lutchman, G..A, Heller, T., et al. 2010. Ribavirin improves early responses to peginterferon through improved interferon signaling, Gastroenterol., 139(1): 154-62.e4.

Flesch, I.E., Wandersee, A., and Kaufmann, S.H. 2000. IL 4 secretion by CD 4 NK T cells induces monocyte, J. Immunol., 159: 7.

Gao, B., and Radaevab, S. 2013. Natural killer and natural killer $\mathrm{T}$ cells in liver fibrosis. Biochimcaet Biophysica (BBA)-Mol. Basis of Dis., 1832(7): 1061-1069.

Godfrey, D., Macdonald, H.R., Kronenberg, M.,
Smyth, M.J. and Van Kaer. 2004. NKT cells: what is in a name? Nat. Rev. Immunol., 4(3): 231-7.

Golden-Manson, L. and Rosen, H.R. 2013. Natural killer cells: multifaceted players with key roles in hepatitis $\mathrm{C}$ immunity. Immunol. Rev., 225: 68-81 doi:10.1111limr.12090.

Golden-Manson, Madrigal-Estebas, Grath, E.M., Conroy, M.J., Ryan, E..J, Hegarty J E, and Doherty D G.2008. Altered natural killer cell subset distribution in resolved and persistent hepatitis $\mathrm{C}$ virus infection following single source exposure Gut, 57:1121-1128.doi:10.1136lgut.

Janeway, C.A. and Medzhitov, R. 2003. Innate immune recognition. Annu. Rev. Immunol., 20: 197-216.

Kawarabayashi, N., Seki, S., Hatsuse, K., et al. 2000. Decrease of $\mathrm{CD}^{2} 6^{+} \mathrm{T}$ cells and natural killer cells in cirrhotic livers with hepatitis $\mathrm{C}$ may be involved in their susceptibility to hepatocellular carcinoma, Hepatol., vol. 32(pg. 962-9).

Kuijpers, T.W., Baars, P.A., Dantin, C., van den Burg, M., van Lier, R.A., and Roosnek E. 2008. Human NK cells can control CMV infection in the absence of T cells, Blood, 112: 914-5.

Lanier, L.L. 2005. NK cell recognition, Апnu. Rev. Immunol., vol. 23 (pg. 225-74).

Lechner, F., Wong, D.K., Dunbar, P.R., Chapman, R., Chung, R.T., Dohrenwend, P., Robbins, G., Phillips, R, Klenerman P, and Walker, B.D. 2000. Analysis of successful immune responses in persons infected with hepatitis C virus. J. Exp. Med., 191: 1499-512.

Lee, S., Watson, M.W., Flexman, J.P., Cheng, W., Hammond, T., and Price, P. 2010. Increased proportion of the CD56(bright) NK cell subset in patients chronically infected with hepatitis $\mathrm{C}$ virus (HCV) receiving interferon-alpha and ribavirin therapy, J. Med. Virol., vol82(pg568-74).

Lizuka, K., Naidenko, O.V., Plougastel, B.F., Fremont, D.H. and Yokoyama, W.M. 2008. Genetically linked C- type lectinrelated ligand for the NKRPI family of 
natural killer cell receptors. Nat. Immunol. A., 801-807.

Lo, K., Brinkman, R.R. and Gottardo, R. 2008. Automated gating of flow cytometry data via robust model based clustering. cytometry part A 73A (4): 321-332.

Meier, U.C., Owen, R.E., Taylor, E., et al. 2005. Shared alterations in NK cell frequency, phenotype, and function in chronic human immunodeficiency virus and hepatitis $\mathrm{C}$ virus infections, J. Virol., vol. 79 (pg. 12365-74).

Mohamoud, A., Yousra, A., Ghina, Suzanne, R., and De Wolfe, M. and Laith J. AbuRaddad.2013.The epidemiology of hepatitis $\mathrm{C}$ virus in Egypt: a systematic review and data synthesis, BMC Infect. Dis., 13:288.

Nandan, S.G., Christine, V., and Stacy, M.H. 2014. Hepatitis C Virus: Strategies to Evade Antiviral Responses Future, Virol., 9(12): 1061-1075.

Neumann, A.U., Lam, N.P., Dahari, H., Gretch, D.R., Wiley, T.E., Layden, T.J., and Perelson, A.S. 2001. Hepatitis C viral dynamics in vivo and the antiviral efficacy of interferon alpha therapy. Sci., 282: 103-7.

Olszak. 2012. Microbial exposure during early life has persistent effects on natural killer T cell function. Sci., 336(6080): 489-93.

Ornatsky, O., Bandura, D., Baranov, V., Nitz, M., Winnik, M.A., and Tanner, S. 2010. Highly multiparametric analysis by mass cytometry. J. Immunol. Method, 361(1-2): $1-20$.

Pembroke, T., Christian, A., Jones, E., Hills, R.K., Wang, E.C.Y., et al. 2014. The paradox of NKP46+ Natural killer cells: drivers of severe hepatitis $\mathrm{C}$ virus induced pathology but in vivo resistance to interferon alpha treatment. Gut, 63: 515524.

Rehermann, B. and Nascimbeni, M. 2005. Immunology of hepatitis B virus and hepatitis C virus infection. Nat. Rev. Immunol., 5: 215-29.

Rivero-Juarez, R., Gonzalez, A., Comacho, et al. 2013. Natural killer KIR3DSI is closely associated with HCV viral clearance and sustained virological response in HIV $\backslash \mathrm{HCV}$ patient, PLoS ONE, vol.8, no.4, Article ID e 61992.

Salem, M.L., Maha, E. and Abdel Raouf, A.N.E. 2010. The potential use of Toll like receptor agonists to restore the dysfunctional immunity induced by hepatitis C virus. Cellular Immunol., 2: 96-104.

Tom, C., Jennifer, A., Yoav, K., and Keith, R. 2012. Invariant NKT cells: regulation and function during viral infection, university of Alberta, Candadoi: 10.1371 \journal.ppat.1002838 August 16.

Torres, A.J., Holowka, D., and Baird, B.A. 2011. Micro patterned ligand arrays to study spatial regulation in Fc receptor signaling. Method Mol. Biol., 748: 195207.

Urbani, S., Amadei, B., Fisicaro, P., Pilli, M., Missale, G., Bertoletti, A., and Ferrari, C. 2005. Heterologous $T$ cell immunity in severe hepatitis $\mathrm{C}$ virus infection. J. Exp. Med., 201: 675-80.

Vivier, E., Spits, H., and Cupedo, T. 2009. New players in mucosal immunity and tissue repair? Nature Review, Immunol., 9: 229234.

\section{How to cite this article:}

Marwa Mostafa Shalaby, Kareman Ahmed Eshra, Radwa Mahmoud Sharaby and Ibrahim Fathy Amer. 2017. Flowcytometric Detection of Natural Killer Cells and Natural Killer T Cells Changes in the Blood of Patients with Chronic Hepatitis C Virus Infection in an Egyptian University Hospital. Int.J.Curr.Microbiol.App.Sci. 6(3): 1506-1518. doi: https://doi.org/10.20546/ijcmas.2017.603.173 